\title{
Does mechanical damage on soybean induces the production of flavonoids?
}

\author{
PAULO LUIZ DA SILVA ${ }^{1}$, GLÁUCIA CORDEIRO ${ }^{1}$, CAROLINA R. DA SILVA ${ }^{1}$, RAFAEL A. BARROS ${ }^{1}$, \\ CAMILA R. DA SILVA ${ }^{2}$, JOSÉ C. ZANUNCIO ${ }^{3}$, WELLINGTON G. CAMPOS ${ }^{4}$ and MARIA G.A. OLIVEIRA ${ }^{1}$
}

\author{
${ }^{1}$ Departamento de Bioquímica e Biologia Molecular, Instituto de Biotecnologia Aplicada a Agropecuária/ \\ BIOAGRO, Universidade Federal de Viçosa, Avenida Peter Henry Rolfs, s/n, 36570-900 Viçosa, MG, Brazil \\ ${ }^{2}$ Instituto de Ciências Agrárias, Campus Rio Paranaíba, Universidade Federal de Viçosa, \\ Rodovia MG 230, Km 7, 38810-000 Rio Paranaíba, MG, Brazil \\ ${ }^{3}$ Departamento de Entomologia, Instituto de Biotecnologia Aplicada a Agropecuária/BIOAGRO, \\ Universidade Federal de Viçosa, Avenida Peter Henry Rolfs, s/n, 36570-900 Viçosa, MG, Brazil \\ ${ }^{4}$ Departamento de Engenharia de Biossistemas, Campus Dom Bosco, Universidade Federal de \\ São João del-Rei, Praça Dom Helvécio, 74, 36301-160 São João del-Rei, MG, Brazil
}

Manuscript received on October 23, 2017; accepted for publication on March 2, 2018

\begin{abstract}
The response of plants to grazing includes the production of chemical defense compounds such as proteases inhibitors and secondary metabolites as flavonoids, which makes them less palatable to feeding and negatively affecting the physiology of insects. The aim of this study was to evaluate the phytochemical response of soybean cultivars (Glycine $\max$ (L.) Merrill) resistant (IAC-17, IAC-24) and susceptible (IAC-P1) to insects after mechanical damage. These cultivars were mechanically injured, and after 24 hours samples of these plants were analyzed by HPLC to identify and quantify flavonoids. The flavonoids daidzein, quercetin, and rutin were quantified, with the highest concentration of daidzin in soybean cultivars after mechanical damage. Rutin was biosynthesized by IAC-24. The cultivars IAC-PL1, IAC-17, and IAC24 did not show a flavonoid response to mechanical damage. The soybean cultivars are not dependent on mechanical damage to produce flavonoids.
\end{abstract}

Key words: Glycine max, flavonoid, herbivory, mechanical damage, secondary metabolite.

\section{INTRODUCTION}

Secondary metabolites are chemical compounds that confer plant resistance to insects. Host plant resistance is an effect strategy used in pest control programs to minimize economic damage (Hoffmann-Campo et al. 2006, Pilon et al. 2009). These metabolites can also be produced by Minthostachys mollis, Ocimum minimum in

Correspondence to: Maria Goreti de Almeida Oliveira

E-mail:malmeida@ufv.br response to mechanical damage (Zabaras and Wyllie 2001, Banchio et al. 2005, Piesik et al. 2006).

Plant response to insect attack can occur directly and/or indirectly. The direct defense against herbivory is the negative effect of secondary metabolites on insect physiology. The indirect defense induces the production of volatile compounds to attract predators (Arimura et al. 2005). The herbivores triggers a chemical signaling to plants to biosynthesize secondary metabolites 
through the shikimate pathway and acetylcoenzyme A (Winkel-Shirley 2001, Mello and Silva-Filho 2002).

Secondary metabolites, as flavonoids and phenolic acids are present in soybean leaves as rutin (Hoffmann-Campo et al. 2006, Stamp and Skrobola 1993, Piubelli et al. 2005, Salvador et al. 2010) daidzin, genistin (Piubelli et al. 2003), salicylic acid, 4-hydroxybenzoic, vanillic acid, 4-hydroxycinnamic acid, ferulic acid, caffeic acid, gentisic, syringic acid, genistein, naringenin, quercetin, and daidzein (Porter et al. 1986).

Flavonoids are essential to plant defense against microorganisms and insects (Dixon and Steele 1999, Simmonds 2001). The flavonoids kaempferol, genistein, quercetin, and naringenin have an antifeedant effect on Coptotermes formosanus (Isoptera: Rhinotermitidae), especially the last two (Ohmura et al. 2000), and the latter causing high mortality of this termite (Boué and Raina 2003). The incorporation of chlorogenic acid, quercetin, and rutin into the diet of caterpillars Helicoverpa armigera (Hübner), Spodoptera litura and Anticarsia gemmatalis Hübner, 1818 (Lepidoptera: Noctuidae) reduced larval weight, caused mortality and increased the pupae period of these insects (Gazzoni et al. 1997, Jadhav et al. 2012).

Mechanically injured plants produce volatile compounds as part of the defense system that can also attract natural enemies. The concentration of volatile compounds like eugenol, linalool, menthone, pulegone, and sesquiterpens increases in mechanically injury $M$. mollis and O. minimum (Zabaras and Wyllie 2001, Banchio et al. 2005, Piesik et al. 2006).

The increased expression of volatile compounds in plants injured are being studied, but the phytochemical flavonoid response in soybean plants needs to be better understood. Therefore, this study objected to investigate the phytochemical flavonoids response in soybean Glycine max (L.)
Merrill cultivars resistant and susceptible to insects, after being undergo mechanical injuries.

\section{MATERIALS AND METHODS}

The experiments were performed at the Laboratory of Enzymology, Biochemistry of Proteins and Peptides, Instituto de Biotecnologia Aplicada a Agropecuária (BIOAGRO) and in the Laboratory of Biodiversity, Department of Biochemistry and Molecular Biology of the Universidade Federal de Viçosa, Minas Gerais State, Brazil.

\section{SOYBEAN CULTIVARS AND PHYTOCHEMICAL RESPONSE TO MECHANICAL DAMAGE}

Seeds of the soybean cultivars IAC-PL1 (susceptible to insects) and IAC-17 and IAC24 (resistant to insects) were obtained from the Instituto Agronômico de Campinas (IAC) of São Paulo State, Brazil, and cultivated until the V3 stage.

Three soybean plants were growner in pots with $4.0 \mathrm{~kg}$ of soil in the green house (temperature $25{ }^{\circ} \mathrm{C} \pm 5$, humidity $70 \% \pm 10$ ) and injured or not with a paper punch ( 6 holes of $0.5 \mathrm{~mm}$ per leaflet). The plants in V3 stage of development control and injured were cultured independently in plastic pots. After 24 hours, nine leaflets were removed from nine plants and were immediately frozen $-80{ }^{\circ} \mathrm{C}$ to phytochemical analysis.

\section{OBTAINING THE LEAF EXTRACT}

The extract of soybean leaves was prepared at $4{ }^{\circ} \mathrm{C}$. The leaves were weighed $(500 \mathrm{mg})$ and pulverized in liquid nitrogen with a mortar and pestle. The powder obtained was transferred to 15 $\mathrm{ml}$ plastic tubes with $5.0 \mathrm{ml}$ of $80 \%$ methanol, kept in an ultrasound bath for $20 \mathrm{~min}$, and centrifuged at $3.000 \mathrm{~g}$ for $5 \mathrm{~min}$ at $4{ }^{\circ} \mathrm{C}$. The supernatants obtained were evaporatedina speed vacuum concentrator and the extracts dry were resuspended with 2 
$\mathrm{ml}$ absolute methanol, filtered with a $0.45 \mu \mathrm{m}$ polytetrafluoroethylene filter, and packed invials.

IDENTIFICATION AND QUANTIFICATION OF FLAVONOIDS BY HIGH PERFORMANCE LIQUID CHROMATOGRAPHY (HPLC)

Aliquots $(30 \mu 1)$ were injected into the chromatograph Shimadzu Prominence System (pump LC-20 AD, Detector SPD-M20A, oven CTO-20A, Lab Solutions program) with a reverse phase column to detecting secondary metabolites (C-18, $4.6 \mathrm{~mm}$ internal diameter, $15 \mathrm{~cm}$ length, 4.8 $\mu \mathrm{m}$ particle diameter).

The extracts were eluted with a segmented gradiente solution of $2 \%$ acetic acid (A) and acetonitrile (B). The chromatographics trength of the mobile phase varied in proportion from $0-4$ $\min , 5 \% \mathrm{~B}$; $4-15 \min 20 \% \mathrm{~B}$; $15-20 \min 35 \% \mathrm{~B}$; 20-30 min $90 \% \mathrm{~B} ; 30-45 \% \mathrm{~B}$, with a temperature of $40{ }^{\circ} \mathrm{C}(\mathrm{CTO}-20 \mathrm{~A})$. The solvent flow was $0.6 \mathrm{ml} /$ min and the absorption measured at $254 \mathrm{~nm}$ (diode array).

The flavonoids in the soybean leaf extracts were evaluated quantitatively by comparison with purchased standards $\left(\right.$ Sigma $\left.^{\circledR}\right)$ by injections of kaempferol, daidzein, daidzein, genistein, genistin, quercetin, and rutin in the HPLC. Calibration curves were made with injection concentrations of daidzein $(1.2,2.4,3.6,4.8 \mathrm{mg})$, quercetin $(0.8$, $1.6,2.4,3.2 \mathrm{mg})$, and rutin $(0.8,1.6,2.4,3.2 \mathrm{mg})$. Linear regression functions were obtained from the responses of these compounds, measured as peak area to calculate the concentration of flavonoids in the samples.

\section{STATISTICAL ANALYSES}

The experiment was conducted in a completely randomized design and the data analyzed with the $\mathrm{R}$ statistical program, considering 5\% error. The experiment had treatments per cultivar, with three replications. The concentration of flavonoid were analyzed for normality with the Shapiro test, and the test of ANOVA and Tukey test were applied. The generalized linear model (GLM) was used to make the analysis ANOVA. Simplifying model was used with GLM.

\section{RESULTS}

\section{IDENTIFICATION OF FLAVONOIDS IN SOYBEAN CULTIVARS}

Soybean cultivars resistant (IAC-17 and 24) and susceptible (IAC-PL1) analyzed by liquid chromatography showed three peaks, identified as the compounds daidzein, quercetin, and rutin (Figure 1).

\section{QUANTIFICATION OF FLAVONOIDS AND THE PHYTOCHEMICAL RESPONSE OF SOYBEAN CULTIVARS}

The concentration of the flavonoids daidzein, quercetin, and rutin in the cultivar IAC-17 differed between them $\left(\mathrm{F}_{2,6}=62.20, \mathrm{p}<0.001\right)$, with 0.207; 0.014 and $0.016 \mathrm{mg} / \mathrm{g}(\mathrm{w} / \mathrm{w})$, respectively. Leaf extract of the IAC-24 showed a higher concentration of daidzein $\left(\mathrm{F}_{2,6}=481.93, \mathrm{p}<0.001\right)$ than that of quercetin and rutin, $0.242 ; 0.011$ and $0.033 \mathrm{mg} / \mathrm{g}$ (w/w), respectively (Figure 2).

The concentration of flavonoids of the IAC 24 (resistant) and IAC PL 1 (susceptible) cultivars showed differences only for the compounds rutin and daidzein $\left(\mathrm{F}_{2,6}=6.91, \mathrm{p}=0.027, \mathrm{~F}_{2,6}=12.23\right.$, $\mathrm{p}=0.007$, respectively), whereas quercetin had a similar value for the IAC-17, IAC-24, and IAC$\operatorname{PL} 1\left(\mathrm{~F}_{2,6}=2.22\right)$ (Figure 3).

Concentrations of daidzein, quecertin, and rutin from IAC-PL1, IAC-17, and IAC-24 with or without mechanical damage were similar (daidzein: $\mathrm{F}_{1,4}=0.07, \mathrm{p}>0.05$, quercetin: $\mathrm{F}_{1,4}=1.56, \mathrm{p}>0.05$, rutin: $F_{1,4}=3, p>0.05$ ) after 24 hours of injury (Table I). 

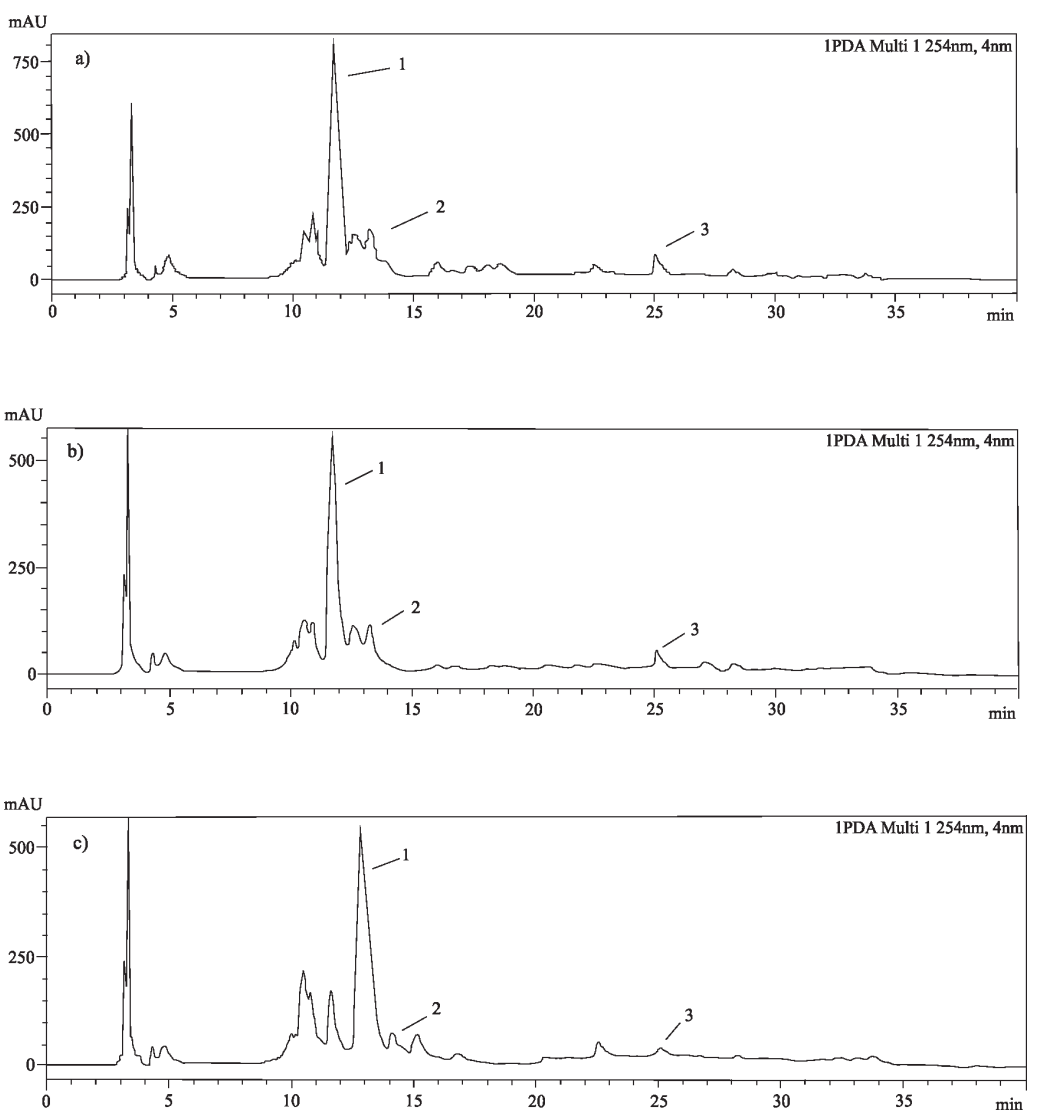

Figure 1 - Chromatograms of the soybean cultivars IAC-17 (a), IAC-24 (b) and IAC-PL1 (c) without mechanical damage. The daidzein compounds (1), retention time - RT $11.6 \mathrm{~min}$, rutin (2), RT $13.7 \mathrm{~min}$ and quercetin (3), TR25 min were monitored under the chromatographic conditions flow $0.06 \mathrm{ml} / \mathrm{min}, 254 \mathrm{~nm}$, column $4.5 \times 15 \mathrm{~cm}$ (ODS - C 18), oven $40{ }^{\circ} \mathrm{C}$, gradient phase (a) water acidified with acetic acid and (b) acetonitrile HPLC.

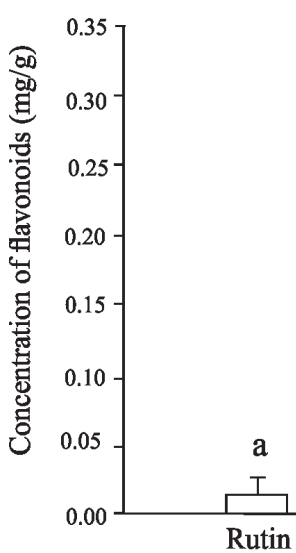

b

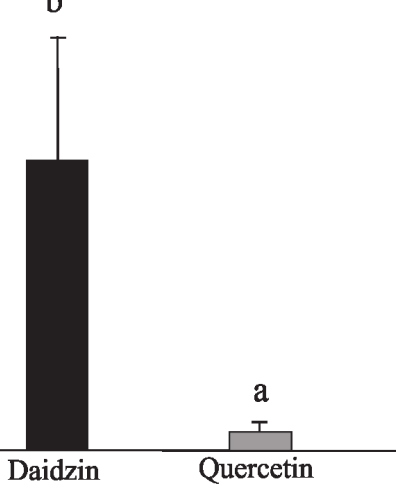

Flavonoids b

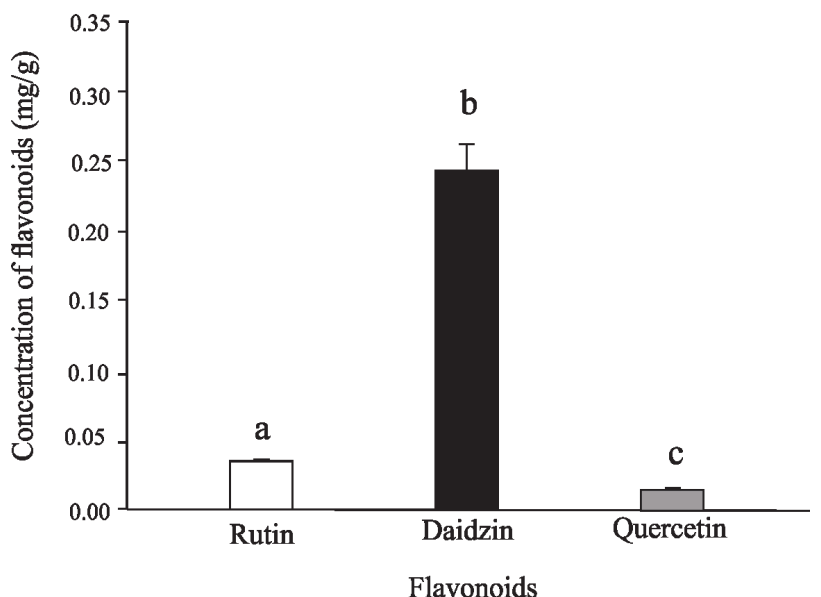

Figure 2 - Flavonoid concentrations in leaf extracts of the insect resistant soybean cultivars IAC-17 (a) and IAC-24 (b) mechanically damaged. Means followed by the same letter are similar between them by ANOVA (IAC-17 $\mathrm{p}<0.001$ and IAC-24 $\mathrm{p}<0.001$ ). 


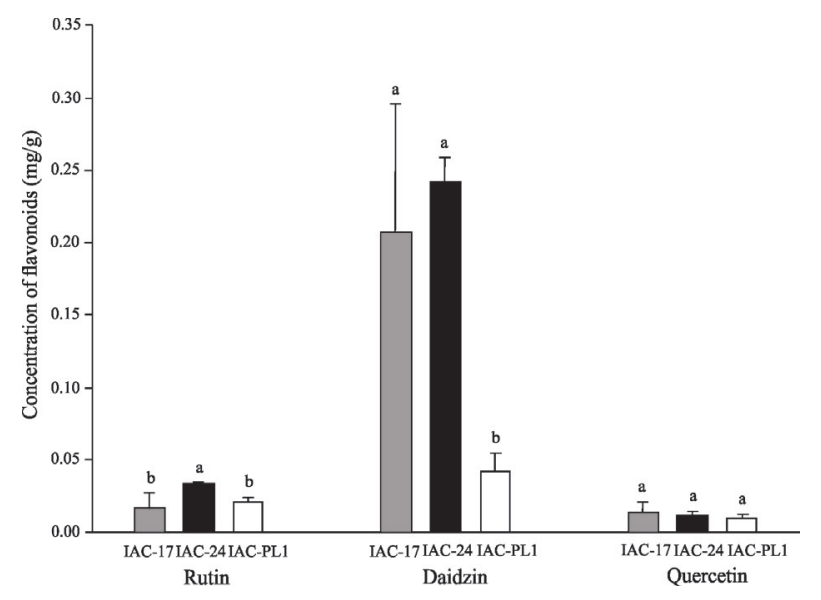

Figure 3 - Flavonoids concentrations in the insect resistant soybean cultivars IAC-17 and IAC-24 and susceptible IACPL1 24h after, mechanically damaged. Means followed by the same letter are similar between them by Tukey test $(p<0.01)$ (Rutin $p=0.027$, Daidzein $p=0.007$, Quercetin $p>0.05$ ).

\section{DISCUSSION}

Flavonoids have diverse biological functions protecting plant against abiotic and biotic factors (Pourcel et al. 2007) including damage by ultraviolet light (Takahashi and Ohnishi 2004) and against microorganisms and insects and they are also responsible for flower colors (Yao et al. 2004, Griesbach 2005).

The quercetin and rutin, wich were detected in lower concentrations in extracts of resistant soybean plants in this work, can cause adverse reactions in pests. Extracts of Hybanthus parviflorus contained rutin which had an insecticidal effecton Ceratitis capitata Wiedemann, 1824 (Diptera: Tephritidae) flies (Broussalis et al. 2010). Rutin found in pods soybean (Hoffmann-Campo et al. 2001, Piubelli et al. 2005) is used in plant breeding programs as a resistance source to defoliating insects. This compound causes antibiotics and/or anti-nutrients in chewing insects (Stamp and Skrobola 1993), including Anticarsia gemmatalis Hübner, 1818 (Lepidoptera: Noctuidae) (Hoffmann-Campo et al. 2006). Ficus sarmentosa var. henryi plant extracts containing quercetin showed an insecticidal effect on Musca domestica Linnaeus, 1758 (Diptera: Muscidae) and Aedes albopictus Skuse, 1894 (Diptera: Culicidae) (Xue-gui et al. 2011). The concentrations of rutinin soybean cultivars resistant to insects ranged from 0.212 to $3.682 \mathrm{mg} / \mathrm{g}$ (Piubelli et al. 2005). The concentration of this compound $(0.033 \mathrm{mg} / \mathrm{g})$ in the cultivar IAC-24 was lower than these values. The daidzein had greatest quantity in soybean plants, but the three chemical compounds may act synergistically against herbivory (Malarvannan et al. 2008). The addition of quercetin and rutin in the diet caused mortality of Helicoverpa armigera caterpillar (Hübner), Spodoptera litura Fabricius, 1775 (Lepidoptera: Noctuidae), and Anticarsia gemmatalis Hübner, 1818 (Lepidoptera: Noctuidae) (Jadhav et al. 2012, Gazzoni et al. 1997).

The concentration of daidzein in the cultivar IAC-24 was approximately 6.3 times higher than that of the quercetin and rutin, which is not observed in the IAC-17. These compounds can affect the physiology of insects, although the mode of action of this phytoestrogens needs to be better studied. Soybean seeds injured by stink bug produced a higher quantity of daidzein and genistein isoflavones, which reduced food quality for insects (Piubelli et al. 2003).

The concentration of flavonoids rutin was 2.5 times higher in the IAC-24 cultivar than in the IAC-17 for $(\mathrm{F}, \mathrm{p}=0.027)$. The concentration of daidzein was 5.7 times higher than the lowest level of cultivar IAC-PL1, susceptible to insects. These concentrations of flavonoids can give rise in these cultivars to increased resistance to insects because these compounds affect the physiology of these organisms (Boué and Raina 2003, Jadhav et al. 2012). Furthermore, it has been shown that in genetically modified tobacco plants increased synthesis of rutin has an insecticidal effect on larvae Spodoptera litura Fabricius, 1775 (Lepidoptera: Noctuidae) and Helicoverpa armigera Hübner, 
TABLE I

Concentration of flavonoids rutin, daidzein and quercetin $(\mathrm{mg} / \mathrm{g})$ in insect resistant and susceptible soybeans with and without mechanical damage.

\begin{tabular}{|c|c|c|c|c|}
\hline \multirow{2}{*}{ Cultivate } & \multirow{2}{*}{ Treatment } & \multicolumn{3}{|c|}{ Flavonoids (mg/g) } \\
\hline & & Rutin & Daidzin & Quercetin \\
\hline \multirow{2}{*}{ IAC-PL1 } & $\mathrm{w}^{1} /$ injury & $0.015 \pm 0.003$ & $0.045 \pm 0.003$ & $0.007 \pm 0.001$ \\
\hline & $w^{2} /$ injury & $0.020 \pm 0.004$ & $0.042 \pm 0.013$ & $0.009 \pm 0.003$ \\
\hline \multirow{2}{*}{ IAC-17 } & $\mathrm{w}^{1} /$ injury & $0.025 \pm 0.012$ & $0.182 \pm 0.087$ & $0.017 \pm 0.006$ \\
\hline & $w^{2} /$ injury & $0.016 \pm 0.011$ & $0.207 \pm 0.089$ & $0.014 \pm 0.007$ \\
\hline \multirow{2}{*}{ IAC-24 } & $\mathrm{w}^{1} /$ injury & $0.039 \pm 0.013$ & $0.263 \pm 0.032$ & $0.012 \pm 0.001$ \\
\hline & wi $i^{2}$ injury & $0.033 \pm 0.001$ & $0.242 \pm 0.017$ & $0.011 \pm 0.003$ \\
\hline
\end{tabular}

$\mathrm{w}^{1}$ : without, $\mathrm{wi}^{2}$ : with. The values did not differ by ANOVA, $\mathrm{p}>0.05$.

1805 (Lepidoptera: Noctuidae), which are important agricultural pests (Pandey et al. 2012).

The cultivars IAC-PL1, IAC-17, and IAC-24 did not show a phytochemical response related to increased flavonoids after $24 \mathrm{~h}$ of mechanical damage. However, mechanically damaged plants tend to express a phytochemical response (Zabaras and Wyllie 2001, Banchio et al. 2005, Piesik et al. 2006), as observed for wheat leaves, where there was an increase in the release of the secondary metabolites linalool (3,7-dimethyl-1,6-octadien3-ol) and linalool oxide (5-ethenyltetrahydro-2furanmethanol) (Piesik et al. 2006). Synthesized compounds due to mechanical damage tend to have lower levels after a certain time (Banchio et al. 2005). The absence of a chemical plant response of plants by producing flavonoids after mechanical damage may be related to the absence of the elicitors $\beta$-glucosidase and volicitin from insects (Alborn et al. 1997). These compounds in contact with the cell membrane of plant can trigger a cascade of signaling and consequently activating ion flows in the plasma membrane, changes in the cytoplasmic calcium concentration, active oxygen generation, and protein phosphorylation (De Bruxelles and Robert 2001). It also induces the jasmonic acid production, responsible for triggering genes in the shikimate and acetyl coenzyme A metabolic pathways, both synthesizers of secondary metabolites (Winkel-Shirley 2001, Mello and Silva-Filho 2002). These metabolites, such as volatiles and terpenes, are produced by mosses in response to herbivory by Coleoptera (Piesik et al. 2011a, 2014). Microorganisms also induce volatile production incorn roots and leaves (Piesik et al. 2011b).

The production of chemical compounds in soybean leaves indicates the need of further studies to understand the flavonoid biosynthesis in these plants. The physiological response or its absence in soybean plants after abiotic stress confirms the importance of studying the potential of flavonoids as part of plant defense against herbivory.

\section{ACKNOWLEDGMENTS}

Thank you for Proof reading the correction work and IAC - Instituto Agronômico de Campinas by the soybean seeds. We thank the Conselho Nacional de Desenvolvimento Científico e Tecnológico (CNPq), Coordenação de Aperfeiçoamento de Pessoal de Nível Superior (CAPES), Fundação de Amparo à Pesquisa do Estado de Minas Gerais (FAPEMIG), and Instituto Nacional de Ciência e Tecnologia em Interações Planta-Praga (INCTIPP), Brazil by the financial support. 


\section{REFERENCES}

ALBORN HT, TURLINGS TC, JONES TH, STENHAGEN G, LOUGHRIN JH AND TUMLINSON JH. 1997. An elicitor of plant volatiles from beet armyworm oral secretion. Sci 276: 945-949.

ARIMURA C, KOST G AND BOLAND W. 2005. Herbivoreinduced, indirect plant defenses. Biochem Biophs Acta 734: 91-111.

BANCHIO E, ZYGADLO J AND VALLADARES G. 2005. Effects of mechanical wounding on essential oil composition and emission of volatiles from Minthostachys mollis. J Chem Ecol 31: 719-727.

BOUÉ SM AND RAINAAK. 2003. Effects of plant flavonoids on fecundity, survival, and feeding of the Formosan subterranean termite. J Chem Ecol 29: 2575-2584.

BROUSSALIS AM, CLEMENTE S AND FERRARO GE. 2010. Hybanthus parviflorus (Violaceae): Insecticidal activity of a South American plant. Crop Prot 29: 953-956.

DE BRUXELLES GL AND ROBERTS MR. 2001. Signals regulating multiple responses to wounding and herbivores. Crit Rev Plant Sci 20: 487-521.

DIXON RA AND STEELE CL. 1999. Flavonoids and isoflavonoids - a gold mine for metabolic engineering. Trends Plant Sci 4: 394-400.

GAZZONI DL, HULSMEYER A AND HOFFMANNCAMPO CB. 1997. Efeito de diferentes doses de rutina e de quercetina na biologia de Anticarsia gemmatalis. Pesq Agropec Bras 32: 673-681.

GRIESBACH RJ. 2005. Biochemistry and genetics of flower color. Plant Breed Rev 25: 89-114.

HOFFMANN-CAMPO CB, HARBONE JB AND MCAFFERY AR. 2001. Pre-ingestive and post-ingestive effects of soya bean extracts and rutin on Trichoplusia ni growth. Entomol Exp Appl 98: 181-194.

HOFFMANN-CAMPO CB, RAMOS NETO JA, OLIVEIRA MCN AND OLIVEIRA LJ. 2006. Detrimental effect of rutina on Anticarsia gemmatalis. Pesq Agropec Bras 41: 1453-1459.

JADHAV DR, MALLIKARJUNA N, RATHORE A AND POKLE D. 2012. Effect of some flavonoids on survival and development of Helicoverpa armigera (Hübner) and Spodoptera litura (Fab) (Lepidoptera: Noctuidae). Asian J Agric Sci 4(4): 298-307.

MALARVANNAN S, SENTHIL KUMAR S, PRABAVATHY VR AND NAIR S. 2008. Individual and synergistic effects of leaf powder of few medicinal plants against American bollworm, Helicoverpa armigera (Hubner) (Noctuidae: Lepidoptera). Asian J Agric Sci 22: 79-88.

MELLO MO AND SILVA-FILHO MC. 2002. Plant-insect interactions: an evolutionary arms race between two distinct defense mechanisms. Braz J Plant Physiol 14(2): 71-81.
OHMURA W, DOI S, AOYAMA M AND OHARA S. 2000. Anti-feedant activity of flavonoids and related compounds against the subterranean termite Coptotermes formosanus shiraki. J Wood Sci 46: 149-153.

PANDEY A, MIRSA P, CHANDRASHEKAR K AND TRIVEDI PK. 2012. Development of AtMYB12expressing transgenic tobacco callus culture for production of rutin with biopesticidal potential. Plant Cell Rep 31: 1867-1876.

PIESIK D, KALKA I, PIESIK AW AND BOCIANOWSKI J. 2014. Apion miniatum Germ. herbivory on the mossy sorrel Rumex confertus Wild: induced plant volatiles and weevil orientation responses. Pol J Envron Stud 23: 21492156.

PIESIK D, LEMNCZYK G, SKOCZEK A, LAMPARSKI R, BOCIANOWSKI J, KOTWICA K AND DELANEY KJ. 2011b. Fusarium infection in maize: volatile induction of infected and neighboring uninfected plant has the potential to attract a pest cereal leaf beetle Oulema melanopus. J Plant Physiol 168: 1534-1542.

PIESIK D, WEAVER DK, PECK GE AND MORRILL WL. 2006. Mechanically-injured wheat plants release greater amounts of the secondary metabolites linalool and linalool oxide. J Plant Prot Res 46: 29-40.

PIESIK D, WENDA-PIESIK A, KOTWICA K, LYSZCZARZ A AND DELANEY A. 2011a. Gastrophysa polygoni herbivory on Rumex confertus: single leaf VOC induction and dose dependent herbivore atraction/repellence to individual compounds. J Plant Physiol 168: 2134-2138.

PILON AM, OLIVEIRA MGA, PILON FM, GUEDES RNC, OLIVEIRA JA AND FAZOLLOS A. 2009. Adaptação da lagarta de soja Anticarsia gemmatalis Hübner (Lepidoptera: Noctuidae) ao inibidor de protease benzamidina. Rev Ceres 56: 744-748.

PIUBELLI GC, HOFFMANN-CAMPO CB, ARRUDA IC, FRACHINI JC AND LARA FM. 2003. Flavonoid increase in soybean as a response to Nezara viridula injury and its effect on insect-feeding preference. J Chem Ecol 29: 1223-1233.

PIUBELLI GC, HOFFMANN-CAMPO CB, MOSCARDI F, MIYAKUBO SH AND OLIVEIRA MCN. 2005. Are chemical compounds important for soybean resistance to A. gemmatalis? J Chem Ecol 31: 1509-1524.

PORTER PM, BANWART WL AND HASSETT JJ. 1986. Phenolic acids and flavonoids in soybean root and leaf extracts. Environ Exp Bot 26: 65-73.

POURCEL L, ROUTABOUL JM, CHEYNIER V, LEPINIEL L AND DABEAUJON I. 2007. Flavonoid oxidation in plants: from biochemical properties to physiological functions. Trends Plant Sci 12: 29-36.

SALVADOR MC, BOIÇA JR AL, OLIVEIRA MCN, GRAÇA JP, SILVA DM AND HOFFMANN-CAMPO CB. 2010. Do different casein concentrations increase the adverse 
effect of rutin on the biology of Anticarsia gemmatalis Hübner (Lepidoptera: Noctuidae). Neotrop Entomol 39: 774-783.

SIMMONDS MSJ. 2001. Importance of flavonoids in insectplant interactions: feeding and oviposition. Phytochem 56: 245-252.

STAMP NE AND SKROBOLA CM. 1993. Failure to avoid rutin diets results in altered food utilization and reduced growth rate of Manduca sexta larvae. Entomol Exp Appl 68: 127-142.

TAKAHASHI A AND OHNISHI T. 2004. The significance of the study about the biological effects of solar ultraviolet radiation using the exposed facility on the internal space station. Biol Sci Space 18: 255-260.
WINKEL-SHIRLEY B. 2001. Flavonoid biosynthesis. A colorful model for genetics, biochemistry, cell biology, and biotechnology. Plant Physiol 126: 485-493.

XUE-GUI W, XIAO-YI W, XING-YAN H, LI-TAO S, YONG-QING T AND HAN-HONG X. 2011. Insecticidal constructure and bioactivities of compounds from Ficus sarmentosa var. henryi. Agric Sci China 10: 1402-1409.

YAO LH, JIANG YM, SHI J, TOMÁS-BARBERAN FA, DATA N, SINGANUSONG R AND CHEN SS. 2004. Flavonoids in food and their health benefits. Plant Foods Hum Nutr 59: 113-122.

ZABARAS D AND WYLLIE SG. 2001. The effect of mechanical wounding on the composition of essential oil from Ocimum minimum L. leaves. Molecules 6: 79-86. 